\title{
Recurrent Childhood Brain Neoplasm
}

National Cancer Institute

\section{Source}

National Cancer Institute. Recurrent Childhood Brain Neoplasm. NCI Thesaurus. Code C7834.

The reemergence of brain neoplasm in childhood after a period of remission. 